\title{
ANALISIS DERAJAT DESENTRALISASI FISKAL DAN KEMANDIRIAN DAERAH KABUPATEN TULANG BAWANG BARAT DAN KABUPATEN PESISIR BARAT TAHUN ANGGARAN 2018-2020
}

\author{
ANALYSIS OF THE DEGREE OF FISCAL DECENTRALIZATION \\ AND REGIONAL AUTONOMY OF TULANG BAWANG BARAT AND \\ PESISIR BARAT DISTRICTS FOR THE 2018-2020 FISCAL YEARS
}

\author{
Rifky Febrihanuddin Azis ${ }^{1}$, Nurul Husna ${ }^{2}$ \\ ${ }^{1}$ Fakultas Ilmu Sosial dan Ilmu Politik, Universitas Lampung \\ ${ }^{2}$ Fakultas Ekonomi dan Bisnis, Universitas Lampung \\ Email : rifkyfebri1@gmail.com
}

Dikirim 2 Juni 2021, Direvisi 8 September 2021, Disetujui 29 November 2021

\begin{abstract}
Abstrak: Berdasarkan Undang-undang Nomor 23 Tahun 2014 tentang Pemerintah Daerah serta Undang-undang Nomor 33 Tahun 2004 tentang Perimbangan Keuangan Antara Pemerintah Pusat dan Daerah. Peraturan tersebut memberikan kesempatan bagi daerah untuk menggali potensi kinerja keuangan dalam rangka mewujudkan kemandirian daerah berasas pada otonomi daerah. Penelitian ini bertujuan untuk mengetahui tingkat kemandirian di Tulang Bawang Barat dan Pesisir Barat yang diukur berdasarkan derajat desentralisasi fiskal dan kemandirian daerah serta faktor-faktor yang berhubungan dengan kemandirian fiskal. Data yang digunakan dalam penelitian ini adalah data sekunder berupa APBD Tahun Anggaran 2018-2020. Data tersebut adalah Total Pendapatan Daerah, Pendapatan Asli Daerah dan Dana Perimbangan. Penelitian ini menggunakan metode deskriptif dengan pendekatan kuantitatif. Hasil penelitian menunjukkan bahwa tingkat kemandirian fiskal di Tulang Bawang Barat dan Pesisir Barat menunjukan pola hubungan instruktif atau sangat rendah, namun rata-rata rasio tingkat kemandirian fiskal di Tulang Bawang Barat lebih tinggi dari pada Pesisir Barat, kontribusi pendapatan asli daerah terhadap penerimaan daerah lebih tinggi di Tulang Bawang Barat dari pada Pesisir Barat, selanjutnya tingkat ketergantungan terhadap bantuan Pemerintah Pusat di Kabupaten Tulang Bawang Barat juga lebih tinggi dari pada tingkat ketergantungan Kabupaten Pesisir Barat. Berdasarkan analisa faktor-faktor yang berhubungan dengan kemandirian fiskal di Tulang Bawang Barat dan Pesisir Barat antara lain partisipasi masyarakat, luas wilayah, dan pertumbuhan produk domestik regional bruto.
\end{abstract}

Kata kunci: Derajat Desentralisasi Fiskal, Kemandirian Daerah

\begin{abstract}
Based on Law Number 23 of 2014 concerning Regional Government and Law Number 33 of 2004 concerning Financial Balance between Central and Regional Government. This regulation provides an opportunity for regions to explore potential financial performance in the context of realizing regional independence based on regional autonomy. This study aims to determine the level of independence in Tulang Bawang Barat and Pesisir Barat which is measured based on the degree of fiscal decentralization and regional independence as well as factors related to fiscal independence. The data used in this research is secondary data in the form of APBD for the 2018-2020 Fiscal Year. The data is Total Regional Revenue, Original Regional Revenue and Balancing Fund. This study uses a descriptive method with a quantitative approach. The results showed that the level of fiscal independence in Tulang Bawang Barat and Pesisir Barat showed an instructive or very low pattern of relationship, but the average ratio of the level of fiscal independence in Tulang Bawang Barat was higher than that of the West Coast, the contribution of local revenue to regional revenues was higher. in Tulang Bawang Barat rather than Pesisir Barat, the level of dependence on Central Government assistance in West Tulang Bawang Regency was also higher than that of Pesisir Barat Regency. Based on the analysis offactors related to fiscal independence in Tulang Bawang Barat and Pesisir Barat, including community participation, area size, and growth of gross regional domestic product.
\end{abstract}

Keywords: Degree of Fiscal Decentralization, Regional Autonomy

\section{PENDAHULUAN}

Indikasi keberhasilan otonomi daerah adalah adanya peningkatan pelayanan dan kesejahteraan masyarakat yang semakin baik, kehidupan demokrasi yang semakin maju, keadilan, pemerataan, serta adanya hubungan yang serasi antara pusat dan daerah serta antar daerah. Keadaan tersebut 
hanya akan tercapai apabila daerah dapat mengelola pemerintahannya dengan diantaranya adalah tata kelola sistem keuangan. Sistem pengelolaan keuangan yang baik akan memberikan manfaat pada efektivitas pelayanan publik dengan pemberian pelayanan yang tepat sasaran, meningkatkan mutu pelayanan publik, biaya pelayanan yang murah karena hilangnya inefisiensi dan penghematan dalam penggunaan sumber daya, alokasi belanja yang lebih berorientasi pada kepentingan publik, dan meningkatkan public costs awareness sebagai akar pelaksanaan pertanggung jawaban publik.

Pemberian otonomi yang luas dan desentralisasi yang sekarang ini dinikmati pemerintah daerah Kabupaten dan Kota, memberikan jalan bagi pemerintah daerah untuk melakukan pembaharuan dalam sistem pengelolaan keuangan daerah dan anggaran daerah. Implementasi desentralisasi fiskal dapat ditemui beberapa hambatan yang terjadi. Salah satu diantaranya adalah adanya disparitas atau kesenjangan pendapatan/kapasitas fiskal dengan kebutuhan pengeluaran/kebutuhan fiskal pada berbagai tingkatan pemerintahan.

Ketidakseimbangan seperti ini akan berakibat fatal bagi upaya mengoptimalkan pembangaunan dan pelayanan publik di pemerintah daerah. Otonomi daerah di Indonesia pada dasarnya adalah kegiatan pemerintah daerah untuk mengatur dan mengurus sendiri urusan pemerintahan dan kepentingan masyarakat setempat sesuai dengan peraturan perundang-undangan (Rahmawati,2011).

Terdapat asumsi bila sumber daya yang dikeluarkan berada dibawah anggaran maka terjadi penghematan dan terjadi pemborosan jika sebaliknya. Pengukuran efisiensi diukur dengan rasio antara input dengan output, bila semakin besar output dibandinkan dengan inputnya maka semakin besar tingkat efisiensi, sehingga ukuran efisiensi mengukur biaya atas output atau seberapa baik organisasi pemerintahan mampu memanfaatkan sumber daya yang dimilikinya untuk menghasilkan output. Sedangkan efektivitas mengukur hasil akhir dari suatu pelayanan dikaitkan dengan output yang dihasilkan (Rusdiana,2017).

Ketidakseimbangan fiskal horizontal ini dapat terjadi karena terdapatnya perbedaan keseimbangan dan pemerataan kemampuan pemerintah khususnya daerah untuk memenuhi pelayanan publik. Besarnya tingkat kemandirian dalam mengelola potensi daerah berpengaruh negatif terhadap tingkat kinerja pelayanan publik daerah (Kartikasari dan Fuad,2014).

Program-program kegiatan pemerintah tidak akan berjalan tanpa adanya sebuah anggaran. Sehingga berkaitan dengan hal tersebut, maka konsep kegesitan yang dibangun dalam penyelenggaraan pemerintah dimulai melalui proses penganggaran yang gesit pula (Adi dan Dian,2021).

Mekanisme pengganggaran program dan kegiatan pemerintah menggunakan sistem birokrasi yang telah baku dan melalui prosedur yang tidak sederhana. Sistem penganggaran pemerintah menggunakan perencanaan hingga penetapan yang pada akhirnya berbentuk Anggaran Pendapatan dan Belanja Negara/Daerah (APBN/D). Keberadaan APBN/D merupakan instrumen fiskal pemerintah untuk membiayai kegiatan pemerintahan dan pembangunan (Saifuddin, 2020). Keberadaan APBN/D tersebut tidak dapat serta merta diubah begitu saja, karena harus melalui tahapan-tahapan yang perlu dilalui.

Tahapan-tahapan tersebut dilakukan dengan tujuan agar anggaran yang notabene berasal dari rakyat tersebut dapat dipertanggungjawabkan dengan baik, atau dapat disebut sebagai dasar dalam menjalankan kepatuhan (compliance) terhadap regulasi.Terlebih lagi apabila dalam realisasi anggaran tidak difokuskan untuk kepentingan pelayanan publik, fakta yang terjadi adalah realisasi anggaran cenderung lebih besar dihabiskan guna belanja pegawai dan untuk pelaksanaan 
penarikan sumber pendapatan daerah bukan untuk kepentingan publik.

Potensi sumber daya manusia dan sumber daya alam yang berbeda pada setiap kabupaten juga menimbulkan perbedaan tingkat kemandirian suatu daerah. Hal ini dapat dilihat dari fasilitas yang ada pada masing-masing daerah, baik itu fasilitas akses jalan maupun fasilitas pengembangan sumber daya manusia yang ada di daerah tersebut. Selain itu, pola hubungan antara pemerintah daerah dengan pemerintah pusat harus dilakukan sesuai dengan kemampuan keuangan daerah dalam hal pembiayaan penyelenggaraan otonomi daerah.

Salah satu hal yang ditimbulkan dari adanya otonomi daerah dan desentralisasi fiskal adalah adanya reformasi pengelola keuangan daerah. Reformasi pengelolaan keuangan daerah yang dimaksud antara lain yakni dalam hal pengelolaan pendapatan daerah dan pengelolaan pengeluaran/belanja daerah. Oleh sebab itu yang menjadi tolak ukur yang akan di lihat dalam kemandirian keuangan daerah adalah pengelolaan penerimaan daerah. Hal lain yang ditimbulkan dari adanya otonomi daerah adalah terjadinya desentralisasi yang merupakan sebuah asas yang hari ini banyak negara di dunia menggunakannya dalam sistem pemerintahannya baik itu negara federal ataupun negara kesatuan. Asas ini merupakan salah satu asas yang terkandung dalam tubuh otonomi daerah. Ketika otonomi daerah dicanangkan oleh pemerintah pusat pada awal tahun 2001, banyak pihak mempertanyakan apakah secara otomatis pencanangan itu akan menimbulkan perubahan paradigma yang mendasar terkait hubungan antara pemerintah pusat dan pemerintah daerah.

Setelah di berlakukannya Undangundang Nomor 23 Tahun 2014 tentang Pemerintah Daerah serta Undang-undang Nomor 33 Tahun 2004 tentang Perimbangan Keuangan Antara Pemerintah Pusat dan Pemerintah Daerah. Adanya otonomi daerah ini diharapkan dapat mewujudkan kemandirian daerah sehingga daerah bebas untuk mengatur rumah tangganya sendiri tanpa adanya campur tangan dari pusat. Namun faktanya pemerintah daerah selalu mengalami minus anggaran dalam pembiayaan rumah tangganya, hal ini disiasati dengan diberinya dana perimbangan yang diberi oleh pemerintah pusat kepada pemerintah daerah. Kabupaten Tulang Bawang Barat dan Kabupaten Pesisir Barat merupakan daerah otonom baru yang memiliki tanggung jawab memberdayakan potensi daerah sesuai prakarsa daerahnya sendiri yang berdasarkan asas transparansi, partisipasi masyarakat dan dapat dipertanggung jawabkan dalam rangka mewujudkan pemerintahan yang baik dan mandiri. Salah satu upaya guna mencapai pemerintahan yang baik dan mandiri tersebut salah satu caranya adalah dengan melaksanakan pengelolaan keuangan dengan baik dan benar.

Untuk meningkatkan pendapatan daerah pada dewasa ini masing-masing daerah di tuntutharus mampu berusaha untuk meningkatkan pendapatannya, maka penggalian potensi ekonomidaerah dan penggunaanpotensi yang tepat adalah jalan terbaik, karena tanpa memperhitungkanpotensi yang dimiliki oleh masing-masing daerah serta tanpa pengembangan pembangunan danpendapatan daerah tidak akan mencapai hasil yang optimal atau sesuai dengan yang diharapkan (Anwar dkk,2015).

Berdasarkan Undang-undang Nomor 50 Tahun 2008 tentang Pembentukan Kabupaten Tulang Bawang Barat dan Undang-undang Nomor 22 Tahun 2012 tentang Pembentukan Kabupaten Pesisir Barat. Kedua kabupaten otonom baru tersebut memiliki persamaan kewenangan wajib yakni melakukan pembangunan daerah sesuai dengan prakarsa daerah yang bersangkutan. Dengan adanya peraturan tersebut Kabupaten Tulang Bawang Barat dan Kabupaten Pesisir Barat berhak melakukan otonomi daerahnya dan mengelola kebijakan anggaranya sesuai dengan kebutuhan daerahnya masing- 
masing dalam rangka kemandirian fiskal daerah. Indikator kemandirian daerah tersebut dapat dilihat dari segi pengeluaran dan pendapatan daerah yang bersangkutan, yang dimana pengeluaran lebih kecil dari pendapatan daerah yang bersangkutan. Berikut merupakan gambar perbandingan antara pendapatan dan pengeluaran daerah Kabupaten Tulang Bawang Barat dengan Kabupaten Pesisir Barat sebagai berikut:

\begin{tabular}{|c|c|c|c|c|c|c|}
\hline \multirow{2}{*}{ Kabupater } & \multicolumn{3}{|c|}{ Anggaran } & \multicolumn{3}{|c|}{ Realisasi } \\
\hline & 2018 & 2019 & 2020 & 2018 & 2019 & 2020 \\
\hline Tulang & Rp. & Rp. & $R p$ & Rp. & Rp. & $R p$ \\
\hline Bawang & 962.270 .704$. & 931.384 .538$. & 988.610 .630 & 946.197 .873$. & 946.904 .183$. & 865.737 .875$. \\
\hline Barat & 871 & 651 & 593 & 628 & 515 & 443 \\
\hline Pesisir & Rp. & Rp. & Rp. & Rp. & Rp. & Rp. \\
\hline Barat & 785.041 .516 & 833.950 .238 . & 874.575 .320$. & 775.333 .888$. & 831.574 .978$. & 804.828.171. \\
\hline & 576 & 460 & 813 & 138 & 358 & 281 \\
\hline
\end{tabular}

Gambar 1. Perbandingan Antara Total Pendapatan Kabupaten Tulang Bawang Barat Sumber: dengan Kabupaten Pesisir Barat

http://www.djpk.kemenkeu.go.id/portal/data/apbd diakses pada Senin 5 Maret 2021 pukul 10:27 WIB

Selanjutnya di bawah ini merupakan gambar perbandingan Pendapatan Asli Daerah antara Kabupaten Tulang Bawang Barat dengan Kabupaten Pesisir Barat sebagai berikut:

\begin{tabular}{|c|c|c|c|c|c|c|}
\hline \multirow{2}{*}{ Kabupaten } & \multicolumn{3}{|c|}{ Anggaran } & \multicolumn{3}{|c|}{ Realisasi } \\
\hline & 2018 & 2019 & 2020 & 2018 & 2019 & 2020 \\
\hline Tulang & Rp. & Rp. & Rp. & Rp. & Rp. & Rp. \\
\hline Bawang & 31.210 .500 .0 & 33.383 .490 .8 & 37.069 .490 .8 & 27.613 .469 .6 & 32.410 .517 .4 & 41.082 .112 .1 \\
\hline Barat & 00 & 25 & 25 & 36 & 00 & 52 \\
\hline Pesisir & Rp. & Rp. & Rp. & Rp. & Rp. & Rp. \\
\hline Barat & 27.998 .961 .5 & 30.167 .124 .6 & 41.773 .684 .6 & 23.481 .041 .7 & 29.323 .369 .7 & 28.747 .196 .3 \\
\hline
\end{tabular}

Gambar 2. Perbandingan Antara Pendapatan Asli Daerah Kabupaten Tulang Bawang Barat dengan Kabupaten Pesisir Barat

Sumber:

http://www.djpk.kemenkeu.go.id/portal/data/apbd diakses pada Senin 5 Maret 2021 pukul 10:30 WIB

Berdasarkan kedua gambar di atas, dapat dilihat bahwa tingkat anggaran dan realisasi Kabupaten Tulang Bawang Barat dan Kabupaten Pesisisr Barat relatif mengalami peningkatan setiap tahunnya. Berdasarkan segi anggaran dan realisasi kedua daerah ini, Kabupaten Tulang Bawang Barat terlihat memiliki selisih perbedaan yang sedikit lebih besar dari Kabupaten Pesisir Barat. Hal ini dapat dilihat dari fasilitas yang ada pada kedua kabupaten tersebut, dimana fasilitas kabupaten Tulang Bawang Barat cenderung lebih berkembang seperti akses transportasi yang sudah memadai. Indikator lain yang dapat digunakan untuk melihat kemandirian fiskal Kabupaten Tulang Bawang Barat dan Kabupaten Pesisir Barat selain dilihat dari segi pendapatan dan realisasi adalah dari segi dana perimbangan kedua kabupaten tersebut.

Dana perimbangan tersebut merupakan dana yang diberikan oleh pemerintah pusat untuk pemerintah daerah yang bersangkutan dalam rangka untuk memenuhi kekurangan pemerintah daerah dan sebagai dana pembantu untuk kemandirian daerah yang bersangkutan. Berikut ini ini merupakan gambar perbandingan Dana Perimbangan antara Kabupaten Tulang Bawang Barat dengan Kabupaten Pesisir Barat sebagai berikut:

\begin{tabular}{lllllll}
\multirow{2}{*}{ Kabupaten } & \multicolumn{3}{c}{ Anggaran } & \multicolumn{3}{c}{ Realisasi } \\
\cline { 2 - 7 } & \multicolumn{2}{c}{2018} & \multicolumn{2}{c}{2019} & \multicolumn{1}{c}{2018} & \multicolumn{2}{c}{2019} & \multicolumn{2}{c}{2020} \\
\hline Tulang & Rp. & Rp. & Rp. & Rp. & Rp. & Rp. \\
Bawang & 726.982 .144$. & 687.570 .522$. & 742.398 .556$. & 725.406 .877$. & 674.827 .807$. & 623.486 .362$. \\
Barat & 000 & 000 & 000 & 464 & 842 & 983 \\
\hline Pesisir & Rp. & Rp. & Rp. & Rp. & Rp. & Rp. \\
Barat & 580.829 .778$. & 592.967 .670$. & 621.070 .567$. & 573.283 .931$. & 587.6533 .782$. & 563.809 .783$. \\
& 000 & 000 & 000 & 025 & 034 & 977 \\
\hline
\end{tabular}

Gambar 3. Tingkat Dana Perimbangan

Sumber:

http://www.djpk.kemenkeu.go.id/portal/data/apbd diakses pada Senin 5 Maret 2021 pukul 10:32 WIB

Berdasarkan data pada tabel di atas, dapat dilihat bahwa tingkat dana perimbangan Kabupaten Tulang Bawang Barat dan Kabupaten Pesisisr Barat relatif mengalami peningkatan setiap tahunnya. Berdasarkan segi anggaran dan realisasi kedua daerah ini, Kabupaten Tulang Bawang Barat terlihat memiliki selisih perbedaan yang sedikit lebih besar dari Kabupaten Pesisir Barat.

\section{LANDASAN TEORI}

\section{A. Konsep Desentralisasi}

Untuk mendukung penulisan jurnal, peneliti juga merasa perlu untuk mendasarkan penulisan pada teori-teori yang telah ada. Sentralisasi dan desentralisasi mempunyai kelebihan dan kekurangan masing-masing. Ini berarti bahwa kekurangan sentralisasi adalah 
kelebihan dari desentralisasi. Menurut Terry dalam Jurnal Wardhanu dan Santosa (2013) mengemukakan tentang kelebihan dari sentralisasi dan desentralisasi adalah sebagai berikut :

1. Kelebihan sentralisasi

a) Keseragaman kebijakan, praktik dan keputusan yang sama;

b) Kekuasaan dan prestise memperlengkap kekuasaan eksekutif;

c) Penggunaan secara ahli-ahli pada kantor pusat, sebagian besar karena mereka dekat kepada manajemen teratas;

d) Ahli-ahli berkualitas tinggi dapat dipergunakan, karena ruang lingkup dan banyaknya pekerjaan mereka adalah cukup untuk membantu manajer;

e) Fungsi rangkap dapat ditekan sampai minimum;

f) Bahaya yang timbul dari tingkah laku dapat dikurangi;

g) Prosedur dan tingkat kontrol yang teliti dan memerlukan biaya besar tidak diperlukan.

h) Dapat dikembangkan kelompok manajemen yang terkooordinasi tepat.

2. Kelebihan desentralisasi

a) Efisiensi dapat ditingkatkan sepanjang struktur dapat dipandang sebagai suatu kebulatan;

b) Lebih berkembang generalis daripada spesialis dan dengan demikian membuka kedudukan untuk manejer umum;

c) Hubungan dan kaitan yang akrab dapat ditingkatkan yang mengakibatkan gairah kerja dan koordinasi yang baik;

d) Kebiasaan dengan aspek kerja yang khusus dan penting siap untuk dipergunakan;

e) Struktur organisasi yang didesentralisasi memperingan beban manajemen teratas, hal ini mendorong tersebarnya beban kerja yang berguna untuk mempercepat proses kerja;

f) Bagi perusahaan yang besar dan tersebar diberbagai tempat, dapat diperoleh manfaatvsebesar-besarnya dari keadaaan tempat masingmasing;

g) Rencana dapat dicoba dalam tahap eksperimen pada suatu perusahaan, dapat diubah dan dibuktikan sebelum diterapkan pada bagian lain yang sejenis dari bagian usahanya yang sama;

h) Resiko yang mencakup kerugian, kepegawaiaan, fasilitas dan perusahaan dapat terbagi.

\section{B. Kebijakan Otonomi Daerah}

Otonomi Daerah merupakan suatu perwujudan pelaksanaan desentralisasi dan merupakan penerapan konsep teori "areal division of power" yang membagi kekuasaan secara vertikal, yaitu daerah dibawahnya. Konsep Desentralisasi atau otonomi daerah merupakan konsekuensi dari bentuk Negara Kesatuan Republik Indonesia, dimana konsep tersebut merupakan sistem perencanaan dan pelaksanaan pembangunan yang akomodatif terhadap inisiatif dan tanggung jawab masyarakat daerah.

Diantara beberapa konsep dan pengertian otonomi daerah, yaitu:

a) Berdasarkan Undang-Undang Nomor 23 Tahun 2014 Tentang Pemerintahan Daerah, dalam ketentuan umum disebutkan bahwa yang dimaksud dengan otonomi daerah adalah hak, wewenang, dan kewajiban daerah otonom untuk mengatur dan mengurus sendiri urusan pemerintahan dan kepentingan masyarakat setempat sesuai dengan peraturan perundangundangan.

b) Menurut Mardiasmo (2004:130), "Penyelengaraan otonomi daerah 
lebih dipahami sebagai hak yaitu hak masyarakat daerah untuk mengatur dan mengelola kepentingannya sendiri serta mengembangkan potensi dan sumber daya untuk memberdayakan masyarakat, menumbuhkan prakarsa dan kreativitas, meningkatkan peran serta masyarakat, serta mengembangkan peran dan fungsi lembaga-lembaga pemerintahan daerah.

c) Menurut Yani (2004:8), "Otonomi Daerah dapat diartikan sebagai hak untuk mengurus rumah tangga sendiri, namun tetap berada pada batas yang tidak melampaui wewenang pemerintah pusat. Dengan kata lain, kewenangan untuk mengurus rumah tangga di negara kita tetap berada dalam konteks dan rambu-rambu Negara Kesatuan Republik Indonesia.“

Dari pengertian diatas dapat dilihat bahwa tujuan diselenggrakan otonomi daerah adalah untuk memberikan hak pada daerah untuk mengatur dan mengurus rumah tangganya sendiri, untuk meningktakan daya guna dan hasil guna penyelenggaraan pemerintahan dan pelayanan masyarakat dalam rangka pembangunan perekonomian daerah yang efektif dan efisien. Otonomi daerah merupakan suatu mekanisme pemberdayaan masyarakat daerah, dengannya daerah mempunyai kekuasaan untuk mengontrol dirinya melalui pembuatan kebijakan publik.. Selain itu, tujuan lain dari diselenggarakan otonomi daerah adalah untuk memberikan kewenangan yang luas, nyata, dan bertanggung jawab kepada daerah secara proporsional yang diwujudkan dengan pengaturan, pembagian dan pemanfaatn sumber daya nasioanal yang berkeadilan, serta perimbangan keuangan pemerintah pusat dan pemerintah daerah, serta lebih ditekankan kepada prinsip-prinsip demokrasi, peran serta masyarakat, dan memperhatikan potensi dan keanekaragaman daerah.

Sedangkan Menurut Undang-Undang Nomor 33 Tahun 2004 Tentang Perimbangan Keuangan Antara Pemerintah Pusat dan Daerah, dalam ketentuan umum disebutkan bahwa yang dimaksud dengan Desentralisasi adalah penyerahan wewenang pemerintahan oleh pemerintah kepada daerah otonom untuk mengatur dan mengurus urusan pemerintahan dalam sistem Negara Kesatuan Republik Indonesia. Istilah desentralisasi tidak mudah untuk didefinisikan karena label ini meliputi suatu susunan kelembagaan yang luas. Tetapi secara umum desentralisasi dapat diartikan sebagai pelimpahan wewenang dari pemerintah pusat ke level pemerintahan yang ada dibawahnya.

Elmi dalam Astuty (2018), mengungkapkan definisi desentralisasi sebagai berikut :

"Desentralisasi berarti memberikan sebagian dari wewenang pemerintah pusat kepada daerah, untuk melaksanakan dan menyelesaikan urusan yang menjadi tanggung jawab dan menyangkut kepentingan daerah yang bersangkutan (otonomi) “

Urusan yang menyangkut kepentingan dan tanggung jawab suatu daerah seperti urusan umum dan pemerintahan, penyelesaian fasilitas pelayanan, serta urusan sosial, budaya, agama dan kemasyarakatan. Parsons dalam Jurnal Astuty (2018) mendefinisikan desentralisasi sebagai berbagi (sharing) kekuasaan pemerintahan antara kelompok pemegang kekuasaan di pusat dengan kelompok-kelompok lainnya, di mana masing-masing kelompok tersebut memiliki otoritas untuk mengatur bidangbidang tertentu dalam lingkup teritorial suatu negara.

Sedangkan Smith dalam Jurnal Astuty (2018) merumuskan definisi desentralisasi sebagai penyerahan kekuasaan dari tingkatan (organisasi) lebih atas ketingkatan lebih rendah, dalam suatu hierarki teritorial, yang dapat saja berlaku 
pada organisasi pemerintah dalam suatu negara, maupun pada organisasi-organisasi besar lainnya (organisasi non pemerintah).

Sedikit berbeda dengan para ilmuwan lainnya, Rondinelli dan Cheema dalam Jurnal Astuty (2018) merumuskan definisi dengan lebih didasarkan pada perspektif administrasi. Desentralisasi merupakan penyerahan wewenang-perencanaan, pengambilan keputusan, dan wewenang administratif (administrative authorities) dari pemerintah pusat kepada: pemerintah daerah, organisasi-organisasi vertikal pemerintah pusat di daerah (field organisations), unit-unit pelaksana administratif di daerah, organisasiorganisasi semi otonom dan organisasi nonpemerintah.

Berdasarkan beberapa pengertian tersebut di atas dapat disimpulkan bahwa desentralisasi merupakan penyerahan wewenang tertentu dari pemerintah pusat kepada pemerintah daerah untuk mengatur urusan-urusan pemerintahan, baik yang bersifat politis maupun administratif dalam rangka mewujudkan tata pemerintahan yang baik. Desentralisasi tidaklah mudah untuk didefinisikan, karena menyangkut berbagai bentuk dan dimensi yang beragam, terutama menyangkut aspek fiskal, politik, perubahan administrasi, dan sistem pemerintahan dan pembangunan sosial serta ekonomi.

Secara umum, konsep desentralisasi menurut Khusaini dalam Jurnal Astuty (2018), terdiri atas desentralisasi politik (political decentralization), desentralisasi administrative (administrative decentralization), desentralisasi fiskal (fiscal decentralization), dan desentralisasi ekonomi (economic or market decentralization).

\section{METODOLOGI}

Berdasarkan judul dan rumusan masalah yang telah dibahas sebelumnya, tipe penelitian yang peneliti gunakan dalam penelitian ini adalah penelitian deskriptif kuantitatif. Metode penelitian deskriptif kuantitatif adalah penelitian yang berlandaskan pada positivisme yang digunakan untuk meneliti populasi atau sampel yang kemudian digambarkan atau dijelaskan menggunakan tabel statistik untuk melihat atau membandingkan hasil dari suatu penelitian (Sugiyono,2012:7).

Tujuan penelitian deskriptif kuantitatif diharapkan untuk menggambarkan objek penelitian menggunakan angka dan disajikan dalam tabel statistik yang bertujuan agar lebih mudah memahami hasil dari suatu penelitian. Variabel yang digunakan dalam penelitian ini adalah variabel mandiri, tanpa menghubungkan antara variabel yang satu dengan variabel yang lain atau tanpa menghubungkan dua variabel atau lebih. Jenis data pada penelitian ini adalah data sekunder yang didapatkan dari sumber-sumber ilmiah dan terpercaya.

Teknik penggunaan data dalam penelitian ini adalah dokumentasi dan studi kepustakaan. Teknik analisis data yang digunakan dalam penelitian ini adalah analisis deskriptif yang dikumpul dan kemudian ditampilkan dalam uraian yang sistematis untuk mengetahui apakah Kabupaten Tulang Bawang Barat dan Kabupaten Pesisir Barat sudah tergolong sebagai kabupaten yang mandiri atau untuk mengetahui lebih mandiri mana antara Kabupaten Tulang Bawang Barat dan Kabupaten Pesisir Barat pada tahun anggaran 2018-2020.

\section{HASIL DAN PEMBAHASAN}

Pemberian otonomi daerah melalui desentralisasi fiskal terkandung tiga misi utama, yaitu meningkatkan kualitas pelayanan umum dan kesejahteraan masyarakat, menciptakan efisiensi dan efektivitas pengelolaan sumber daya daerah dan memberdayakan dan menciptakan ruang bagi masyarakat untuk ikut serta dalam proses pembangunan. Kebijakan desentralisasi bertujuan untuk mengatasi ketidakefektifan dan ketidakefisienan pemerintah pusat, ketidakstabilan makro ekonomi serta meningkatkan pertumbuhan ekonomi. Beberapa ahli menyatakan bahwa 
sasaran utama desentralisasi adalah dapat membantu mempercepat perkembangan pertumbuhan ekonomi di daerah serta desentralisasi merupakan sebuah solusi agar pemerintah dapat lebih efisien dalam menjalankan roda pemerintahannya dari tingkat yang lebih rendah (tricckle down effect) sehingga lebih cepat tanggap membantu masyarakat di daerah tersebut agar perekonomian dapat dijalankan tanpa adanya hambatan-hambatan yang dapat menunda pertumbuhan ekonomi di daerah dalam rangka mencapai kesejahteraan masyarakat.

Pemerintah daerah memiliki kelebihan dalam membuat anggaran pembelanjaan sehingga lebih efisien dengan memuaskan kebutuhan masyarakat karena lebih mengetahui keadaannya. Desentralisasi fiskal diharapkan akan dapat mampu meningkatkan pertumbuhan ekonomi dan kesejahteraan untuk masyarakat, karena pemerintah daerah akan lebih mengefisienkan dalam belanja produksi dan penyediaan barang-barang publik. Pengambilan keputusan pada level pemerintah lokal akan lebih didengarkan untuk menganekaragamkan pilihan lokal dan lebih berguna bagi efisensi alokasi. Desentralisasi fiskal di beberapa daerah berkembang apabila tidak berpegang pada standar teori desentralisasi, hasilnya mungkin akan merugikan pertumbuhan ekonomi dan efisiensi. Selain itu, desentralisasi fiskal diharapkan akan mampu meningkatkan efisiensi ekonomi yang kemudian berkaitan dengan dinamika pertumbuhan ekonomi.

Sektor belanja infrastruktur dan sektor belanja sosial oleh pemerintah daerah lebih memacu pertumbuhan ekonomi dari pada kebijakan pemerintah pusat Pertumbuhan ekonomi hanya akan menghasilkan perbaikan distribusi pendapatan dan kesejahteraan bila memenuhi setidaktidaknya dua syarat, yaitu memperluas kesempatan kerja dan meningkatkan produktivitas. Dengan kata lain meluasnya kesempatan kerja, akses rakyat untuk memperoleh penghasilan akan semakin besar. Dalam jangka panjang, kesempatan kerja yang tersedia memaksa orang untuk menentukan spesialisasi yang akan meningkatkan produktivitas. Meningkatnya produktivitas, maka uang yang dihasilkan untuk jam kerja yang sama akan lebih besar.

Uang tersebut digunakan untuk memperbaiki kualitas SDM generasi berikutnya. Begitupun seterusnya, sehingga dalam beberapa generasi kemudian, distribusi pendapatan makin membaik serta kesejahteraan makin meningkat. Kebijakan perimbangan keuangan antara Pemerintah pusat dan Pemerintah daerah dilakukan dengan mengikuti pembagian kewenangan. Hal ini menjelaskan bahwa hubungan keuangan antara Pusat dan Daerah perlu diberikan pengaturan dalam bentuk peraturan, sehingga kebutuhan pengeluaran yang akan menjadi tanggungjawab daerah dapat dibiayai dari sumber-sumber penerimaan yang ada. Sejalan dengan pembagian kewenangan yang telah disebutkan sebelumnya maka pengaturan pembiayaan Daerah dilakukan berdasarkan azas desentralisasi, dekonsentrasi dan tugas pembantuan.

Pembiayaan pemerintahan berdasarkan asas desentralisasi dilakukan atas beban APBD, pembiayaan penyelenggaraan pemerintahan dalam rangka pelaksanaan azas dekonsentrasi dilakukan atas beban APBN dan pembiayaan penyelenggaraan pemerintahan dalam rangka tugas pembantuan dibiayai atas beban anggaran tingkat pemerintahan yang menugaskan. Selanjutnya dalam rangka penyelenggaraan pemerintahan dan pelayanan kepada masyarakat berdasarkan azas desentralisasi, kepada Pemerintah Daerah yang diberikan kewenangan untuk memungut pajak/retribusi (tax assignment) dan pemberian bagi hasil penerimaan (revenue sharing) serta bantuan keuangan (grant) atau dikenal sebagai dana perimbangan sebagai sumber dana bagi APBD.

Secara umum, sumber dana bagi daerah terdiri dari pendapatan asli daerah, dana 
perimbangan (dana bagi hasil, dana alokasi umum, dan dana alokasi khusus) dan pinjaman daerah, dekonsentrasi dan tugas pembantuan.

Dana Bagi Hasil (DBH) Dana bagi hasil adalah dana yang bersumber dari APBN yang dibagihasilkan kepada daerah berdasarkan angka persentase tertentu dengan memperhatikan potensi daerah penghasil. Dana bagi hasil terdiri dari dana bagi hasil bersumber dari pajak dan dana bagi hasil sumber daya alam. Penjelasan umum Undang-undang Nomor 33 Tahun 2004 mengandung pengertian bahwa pengalokasian Dana Bagi Hasil pada APBN merupakan pendapatan yang diperoleh dari sumber-sumber daya nasional yang berada di daerah berupa pajak dan sumber daya alam.

Dana Bagi Hasil merupakan dana perimbangan yang strategis bagi daerahdaerah yang memiliki sumber-sumber penerimaan pusat di daerahnya, meliputi penerimaan pajak pusat dan penerimaan dari sumber daya alam. Besarnya dana bagi hasil dari pajak maupun sumber daya alam ditetapkan berdasarkan persentase tertentu. Dana Alokasi Umum, selanjutnya disebut DAU adalah dana yang bersumber dari pendapatan APBN yang dialokasikan dengan tujuan pemerataan kemampuan keuangan antar daerah untuk mendanai kebutuhan daerah dalam rangka pelaksanaan desentralisasi (Undangundang Nomor 33 Tahun 2004, Pasal 1 ayat 21). DAU dialokasikan berdasarkan persentase pendapatan dalam negeri yang ditetapkan dalam APBN.

DAU untuk suatu daerah ditetapkan berdasarkan kriteria tertentu yang menekankan pada aspek pemerataan dan keadilan yang selaras dengan penyelenggaraan urusan pemerintahan yang formula dan perhitungan DAU-nya ditetapkan sesuai Undang-undang. Dana Alokasi Khusus (DAK) adalah dana yang bersumber dari pendapatan APBN yang dialokasikan kepada daerah tertentu dengan tujuan membantu mendanai kegiatan khusus yang merupakan urusan daerah dan sesuai dengan prioritas nasional". Sesuai dengan Undang-Undang No. 33 Tahun 2004 tentang perimbangan keuangan antara Pemerintah Pusat dan Pemerintah Daerah, kegiatan khusus yang dimaksud adalah

1. Kegiatan dengan kebutuhan yang tidak dapat diperkirakan dengan rumus alokasi umum, dalam pengertian kebutuhan suatu daerah tidak sama dengan kebutuhan daerah lain, misalnya kebutuhan di kawasan transmigrasi, kebutuhan beberapa jenis investasi/prasarana baru, pembangunan jalan di kawasan terpencil, serta saluran irigasi primer.

2. Kebutuhan yang merupakan komitmen atau prioritas nasional. Wijaya (2007:112) menambahkan kriteria pengalokasian DAK, yaitu:

a. Kriteria Umum, dirumuskan berdasarkan kemampuan keuangan daerah yang tercermin dari penerimaan umum APBD setelah dikurangi belanja PNS;

b. Kriteria Khusus, dirumuskan berdasarkan peraturan perundangundangan yang mengatur penyelenggaraan otonomi khusus dan karakteristik daerah; dan

c. Kriteria Teknis, yang disusun berdasarkan indikator-indikator yang dapat menggambarkan kondisi sarana dan prasarana, serta pencapaian teknis pelaksanaan kegiatan DAK di daerah.

Hubungan keuangan antara pemerintah pusat dengan daerah yang secara formal mulai diatur dalam Undang Undang Nomor 33 Tahun 2004 tentang Perimbangan Keuangan antara Pemerintah Pusat dengan Daerah dan secara praktik diwujudkan dalam bentuk transfer dana perimbangan serta hak dan kewenangan memungut sumber pendapatan di daerah disebut sebagai desentralisasi fiskal. Menurut Bahl dan Linn (1992) desentralisasi fiskal berarti desentralisasi dari pemerintahan, alokasi pengeluaran dan mobilisasi penerimaan daerah. Bahl juga menyebutkan bahwa bentuk desentralisasi fiskal sangat bervariasi tergantung sistem pemerintahannya. 
Pada satu titik ekstrim tertentu negara cenderung membatasi desentralisasi sehingga pemerintah daerah tidak bisa leluasa melakukan pembiayaan dan pelayanan publik. Sedangkan di titik ekstrim lainnya, pemerintah lokal diberikan kekuasaan penuh dalam mengelola sumbersumber keuangan di daerahnya.

Desentralisasi fiskal dan otonomi daerah berikutnya menjadi konsep yang selalu seiring sejalan; dalam artian bahwa pelaksanaan otonomi daerah salah satunya diwujudkan dalam bentuk desentralisasi fiskal dan sebaliknya bahwa tingginya derajat desentralisasi fiskal akan menjadi indikator dari keberhasilan pelaksanaan otonomi daerah. Desentralisasi fiskal adalah pilihan wajib bagi suatu negara berbentuk kesatuan untuk membangun pola hubungan yang baik dan selaras antara unit pemerintahan baik secara vertikal maupun horizontal.

Secara vertikal, hubungan pemerintah pusat dengan pemerintah daerah akan berjalan harmonis apabila daerah merasa bahwa kewenangan untuk mencari sumber pendanaan di daerah sesuai dengan urusan pemerintahan yang diembannya. Adapun secara horizontal, desentralisasi fiskal yang adil yang diberikan oleh pemerintah pusat akan meniadakan kesenjangan yang terlalu lebar antar satu daerah dengan daerah lain, baik antar provinsi maupun antar kabupaten/kota dalam satu wilayah provinsi. Secara teori, salah satu indikator keberhasilan pembangunan daerah adalah jumlah penduduk miskin, dalam artian bahwa penurunan jumlah penduduk miskin adalah indikasi dari keberhasilan pembangunan, begitu pula sebaliknya bahwa kenaikan jumlah penduduk miskin adalah indikasi dari kegagalan pembangunan.

Oleh karena itu, jumlah penduduk miskin adalah salah satu ukuran atau dampak akhir dari penyelenggaraan pemerintahan. Keberhasilan pembangunan daerah tidak bisa hanya dibahas dalam konteks dampak namun juga terkait pada aspek penyebab atau pendorongnya. Dalam konteks ini, implementasi desentralisasi fiskal berada pada posisi penyebab atau pendorong keberhasilan otonomi daerah dimaksud. Sebagai tujuan atau dampak antara, desentralisasi fiskal adalah salah satu strategi utama untuk mendorong terwujudnya kemampuan keuangan daerah sehingga daerah mampu untuk menyelenggarakan pembangunan dan pelaksanaan fungsi-fungsi pemerintahan dengan maksimal.

Berikutnya desentralisasi fiskal sekaligus dapat menjadi jalan untuk mewujudkan kemandirian daerah sebagai tujuan akhir dari pelaksanaan otonomi daerah. Dalam konteks tersebut maka terdapat relasi yang sangat erat antara desentralisasi fiskal dan kemandirian daerah sehingga idealnya desentralisasi fiskal harus mampu meningkatkan kemandirian daerah bukan hanya pada aspek pertumbuhan ekonomi semata. Indikator kemandirian daerah sebagai implikasi desentralisasi fiskal dalam penelitian ini akan dijelaskan pada aspek makro-ekonomi dan aspek kesehatan fiskal

Berikut ini merupakan hasil pembahasan dalam penelitian Derajat Desentralisasi Fiskal dan Kemandirian Daerah Kabupaten Tulang Bawang Barat sebagai berikut:

\section{Berdasarkan Aspek PAD Tahun Anggaran 2018-2020:}

PAD 2018/TPD $2018 \times 100 \%=(R p$. 31.210.500.000)/(Rp. 962.270.704.871) x $100 \%=3.24 \%$

PAD 2019/TPD $2019 \times 100 \%=$ (Rp.33.383.490.825)/(Rp.931.384.538.651) $\mathrm{x} 100 \%=3.58 \%$

PAD 2020/TPD $2020 \times 100 \%=(\mathrm{Rp}$. 37.069.490.825)/(Rp. 988.610.630.593) $\mathrm{x}$ $100 \%=3.74 \%$

\footnotetext{
Berdasarkan Aspek BHPBP Tahun Anggaran 2018-2020:

BHPBP 2018/TPD $2018 \times 100 \%=(\mathrm{Rp}$. 23.650.782.000)/(Rp. 962.270.704.871) x $100 \%=2.45 \%$
} 
BHPBP 2019/TPD $2019 \times 100 \%=(\mathrm{Rp}$. 15.826.109.000)/(Rp. 931.384.538.651) $\mathrm{x}$ $100 \%=1.69 \%$

BHPBP 2020/TPD $2020 \times 100 \%=(\mathrm{Rp}$. 18.017.505.000)/(Rp. 988.610.630.593) x $100 \%=1.82 \%$

\section{Berdasarkan Aspek Sumbangan Bantuan Tahun Anggaran 2018-2020:}

SB 2018/TPD $2018 \times 100 \%=(\mathrm{Rp}$. 703.331.362.000 )/(Rp. 962.270.704.871) $\mathrm{x} 100 \%=73.09 \%$

SB 2019/TPD $2019 \times 100 \%=(\mathrm{Rp}$. 671.744.413.000 )/(Rp. 931.384.538.651) $\mathrm{x} 100 \%=72.13 \%$

SB 2020/TPD $2020 \times 100 \%=(\mathrm{Rp}$. 724.381.051.000)/(Rp. 988.610.630.593) x $100 \%=73.27 \%$

Berdasarkan laporan dari Gambar 2 tentang pendapatan asli daerah bahwasanya dari segi nominal angka rupiah pendapatan asli daerah Kabupaten Tulang Bawang Barat cukup meningkat hal ini dibuktikan dengan data yang terdapat di lampiran bahwasanya pendapatan dari sektor pajak, retribusi, laba atas perusahaan daerah dan pendapatan lain-lain yang sah seperti jasa giro kas daerah cukup signifikan perubahannya, namun bila ditinjau dari aspek kemandirian keuangan daerah Kabupaten Tulang Bawang Barat yang notabene masih tergolong Kabupaten baru masih sangat kurang, bila kita melihat tingkat persentase Bagi Hasil Pajak Bukan Pajak (BHPBH) seperti bagi hasil pajak dari Provinsi terkait pajak bumi bangunan, pajak penghasilan dan pajak pertambangan sangat kurang akan tetapi dari Sumbangan Daerah (DAU dan DAK) yang dananya di dapat dari APBN kita melihat tabulasi data diatas nominalnya dari tahun ke tahun sangat besar. Sebaiknya setiap tahunnya Sumbangan Daerah pada setiap Kabupaten semakin turun diikuti dengan naiknya Pendapatan Asli Daerah di Kabupaten, bukan yang setiap tahunnya selalu mendapatkan bantuan dari Pusat terkait Dana Perimbangan.
Hal tersebut memang menjadi tugas berat seorang pemimpin dimana seorang pemimpin dituntut untuk membuat kebijakan strategis untuk membangun daerahnya. Membangun daerah yang mandiri dapat dilakukan dengan mengoptimalkan potensi daerah dan memberdayakan masyarakat berbasis gotong royong. Tulang Bawang Barat merupakan salah satu Kabupaten yang saat ini sedang gencar membangun paradgima daerah wisata, dengan banyaknya pembangunan di sektor wisata untuk dapat menarik minat wisatawan berkunjung ke Tulang Bawang Barat seperti Islamic Center Tulang Bawang Barat, Taman Agro Wisata Tubaba, Monumen Megou Pak yang saat ini sedang dibangun dan lain sebagainya. Mengoptimalisasi potensi daerah dapat diterapkan dengan memitigasi risiko peluang dan kegagalan terlebih dahulu. Dengan memitigasi risiko terlebih dahulu seorang pemimpin akan mendapatkan strategi untuk meningkatkan potensi daerah sehingga pendapatan yang berasal dari daerah bisa dikelola dengan baik sesuai dengan asas good governance.

Berikut ini merupakan hasil pembahasan dalam penelitian Derajat Desentralisasi Fiskal dan Kemandirian Daerah Kabupaten Pesisir Barat sebagai berikut:

\section{Berdasarkan Aspek PAD Tahun Anggaran 2018-2020:}

PAD 2018/TPD $2018 \times 100 \%=(\mathrm{Rp}$. 27.998.961.576)/(Rp.785.041.516.576 ) $\mathrm{x}$ $100 \%=3.56 \%$

PAD 2019/TPD $2019 \times 100 \%=(\mathrm{Rp}$. 30.167.124.632)/(Rp. 833.950.238.460) x $100 \%=3.61 \%$

PAD 2020/TPD $2020 \times 100 \%=(\mathrm{Rp}$. 41.773.684.633)/(Rp. 874.575.320.813 ) x $100 \%=4.77 \%$

\section{Berdasarkan Aspek BHPBP Tahun Anggaran 2018-2020: \\ BHPBP 2018/TPD $2018 \times 100 \%=(\mathrm{Rp}$. 21.575.069.000)/(Rp.785.041.516.576 ) x $100 \%=2.74 \%$}


BHPBP 2019/TPD $2019 \times 100 \%=$ (Rp.13.224.276.000 )/(Rp. $833.950 .238 .460) \times 100 \%=1.58 \%$

BHPBP 2020/TPD $2020 \times 100 \%=(\mathrm{Rp}$. 16.145.382.000)/(Rp. 874.575.320.813) x $100 \%=1.84 \%$

\section{Berdasarkan Aspek Sumbangan Bantuan Tahun Anggaran 2018-2020:}

SB 2018/TPD $2018 \times 100 \%=(\mathrm{Rp}$. 559.254.709.000)/(Rp. 785.041.516.576 ) $\mathrm{x} 100 \%=71.23 \%$

SB 2019/TPD 2019 × 100\% = (Rp. 579.743.394.000 )/(Rp. 833.950.238.460) $\mathrm{x} 100 \%=69.51 \%$

SB 2020/TPD $2020 \times 100 \%=(\mathrm{Rp}$. 604.925.185.000)/(Rp. 874.575.320.813 ) x $100 \%=69.16$

Berdasarkan laporan dari Gambar 2 tentang pendapatan asli daerah bahwasanya dari segi nominal angka rupiah pendapatan asli daerah Kabupaten Pesisir Barat cukup meningkat setiap tahunnya, hal ini dibuktikan dengan data yang terdapat di lampiran bahwasanya pendapatan dari sektor pajak, retribusi, laba atas perusahaan daerah dan pendapatan lain-lain yang sah seperti jasa giro kas daerah cukup signifikan perubahannya, namun bila ditinjau dari aspek kemandirian keuangan daerah Kabupaten Pesisir Barat yang notabene masih tergolong Kabupaten sangat baru masih sangat kurang, bila kita melihat tingkat persentase Bagi Hasil Pajak Bukan Pajak (BHPBH) seperti bagi hasil pajak dari Provinsi terkait pajak bumi bangunan, pajak penghasilan dan pajak pertambangan sangat kurang akan tetapi dari Sumbangan Daerah (DAU dan DAK) yang dananya di dapat dari APBN kita melihat tabulasi data diatas nominalnya dari tahun ke tahun sangat besar. Sebaiknya setiap tahunnya Sumbangan Daerah pada setiap Kabupaten semakin turun diikuti dengan naiknya Pendapatan Asli Daerah di Kabupaten, bukan yang setiap tahunnya selalu mendapatkan bantuan dari Pusat terkait Dana Perimbangan. Hal tersebut memang menjadi tugas berat seorang pemimpin dimana seorang pemimpin dituntut untuk membuat kebijakan strategis untuk membangun daerahnya. Membangun daerah yang mandiri dapat dilakukan dengan mengoptimalkan potensi daerah dan memberdayakan masyarakat berbasis gotong royong. Pesisr Barat merupakan salah satu Kabupaten yang saat ini sedang gencar membangun paradgima daerah wisata terutama di industri wisata bahari, dengan banyaknya pembangunan di sektor wisata bahari untuk dapat menarik minat wisatawan lokal dan mancanegara berkunjung ke Pesisir Barat seperti pengembangan Tanjung Setia, Labuhan Jukung, Pulau Pisang, cottage atau villa yang saat ini sedang menjamur di Kabupaten tersebut. Mengoptimalisasi potensi daerah dapat diterapkan dengan memitigasi risiko peluang dan kegagalan terlebih dahulu. Dengan memitigasi risiko terlebih dahulu seorang pemimpin akan mendapatkan strategi untuk meningkatkan potensi daerah sehingga pendapatan yang berasal dari daerah bisa dikelola dengan baik sesuai dengan asas good governance. Secara umum saran dari peneliti terhadap hasil penelitian ini adalah Kemandirian Fiskal di Kabupaten Tulang Bawang Barat dan Kabupaten Pesisir Barat selalu mengalami peningkatan. Namun masih terdapat berbagai kekurangan, oleh karena itu peneliti merekomendasikan beberapa saran terkait Kemandirian Fiskal di Kabupaten Tulang Bawang Barat dan Kabupaten Pesisir Barat sebagai berikut:

1. Pemerintah Daerah Kabupaten Tulang Bawang Barat dan Kabupaten Pesisir Barat sebaiknya memperbaiki sistem perpajakan daerah, seperti melakukan administrasi penerimaan daerah agar menjamin semua pendapatan terkumpul dengan baik, pelaporan hasil pengumpulan pajak dan retibusi daerah perlu dimonitoring secara efektif sehingga pendapatan dari sektor pajak daerah cukup besar.

2. Pemerintah Kabupaten Tulang Bawang Barat dan Kabupaten Pesisir Barat harus lebih optimal dalam menggali potensi 
Pendapatan Asli Daerah agar peningkatan kemandirian fiskal dapat terjadi pada kedua kabupaten.

3. Pemerintah Kabupaten Tulang Bawang Barat dan Kabupaten Pesisir Barat sebaiknya mengadakan penyuluhan dan sosialisasi kepada msyarakat hingga timbul kesadaran membayar pajak demi pembangunan daerah

\section{KESIMPULAN}

Berdasarkan hasil penelitian yang telah dilakukan dapat diambil kesimpulan bahwa kemandirian fiskal Kabupaten Tulang Bawang Barat dan Kabupaten Pesisir Barat tahun 2018-2020 masih rendah dan bantuan dari Pemerintah pusat masih dominan dalam bantuan keuangan daerah di Kabupaten Tulang Bawang Barat dan Kabupaten Pesisir Barat. Adapun rincian kesimpulan sebagai berikut:

1. Kemandirian fiskal di Kabupaten Tulang Bawang Barat dan Kabupaten Pesisir Barat menunjukan hasil yang belum mandiri dengan pola hubungan Instruktif dengan perbandingan tingkat kemandirian fiskal masih tinggi di Kabupaten Pesisir Barat dibandingkan dengan Kabupaten Tulang Bawang Barat.

2. Kontribusi Pendapatan Asli Daerah terhadap Penerimaan Daerah di Kabupaten Pesisir Barat lebih unggul dari Kabupaten Tulang Bawang Barat dengan rata-rata rasio sebesar 4,01 persen pada Kabupaten Pesisir Barat dan 3,52 persen pada Kabupaten Tulang Bawang Barat. Dengan angka tersebut menunjukan bahwa kontribusi PAD dirasa masih relatif rendah pada kedua kabupaten.

3. Kontribusi Bantuan Pemerintah terhadap total Pandapatan Daerah di Kabupaten Tulang Bawang Barat dan Kabupaten Pesisir Barat relatif cukup besar, dengan rata-rata rasio sebesar 72,83 persen pada Kabupaten Tulang Bawang Barat dan 69,96 persen pada Kabupaten Pesisir Barat. Angka tersebut menunjukan bahwa ketergantungan Pemerintah Kabupaten Tulang Bawang Barat terhadap Pemerintah
Pusat lebih besar dibanding dengan Kabupaten Pesisir Barat.

4. Kontribusi Dana Bagi Hasil Pajak Bukan Pajak di Kabupaten Tulang Bawang Barat dan Kabupaten Pesisir Barat menunjukan pertumbuhan yang fluktuatif dengan rata-rata rasio sebesar 1,98 persen pada Kabupaten Tulang Bawang Barat dan 3,03 persen pada Kabupaten Pesisir Barat. Berdasarkan angka tersebut menunjukan bahwa pertumbuhan kontribusi dana bagi hasil pajak bukan pajak dari Pemerintah Provinsi kepada Kabupaten Pesisir Barat lebih tinggi dibanding dengan Kabupaten Tulang Bawang Barat.

5. Faktor-faktor yang berhubungan dengan kemandirian fiskal Kabupaten Tulang Bawang Barat dan Kabupaten Pesisir Barat antara lain yakni:

a. Faktor partisipasi masyarakat dalam membayar pungutan dari pemerintah di Kabupaten Tulang Bawang Barat lebih tinggi dari Kabupaten Pesisir Barat, sehingga dapat dikatakan bahwa tingkat kemandirian di Kabupaten Tulang Bawang Barat lebih tinggi dari Kabupaten Pesisir Barat.

b. Faktor tingginya laju pertumbuhan Pendapatan Domestik Regional Bruto pada Kabupaten Pesisir Barat mengakibatkan Kemandirian Fiskal di Kabupaten Pesisir Barat lebih cepat berkembang dibandingkan dengan Kabupaten Tulang Bawang Barat. Hal ini mengakibatkan Kabupaten Pesisir Barat lebih mandiri dari segi fiskal dibandingkan dengan Kabupaten Tulang Bawang Barat.

Selain itu terdapat juga pengaruh Desentralisasi Fiskal terhadap pertumbuhan ekonomi seperti beberapa ahli yang mendukung desentralisasi antara lain dikemukakan oleh Tiebout (1956), Oates (1972), Tresch (1981), Breton (1996), Weingast (1995), dan sebagaimana dikutip oleh Litvack et al (1998:311), yang mengatakan bahwa pelayanan publik yang paling efisien seharusnya diselenggarakan oleh wilayah yang memiliki kendali geografis yang paling minimum karena : 
a. Pemerintah lokal sangat menghayati kebutuhan masyarakatnya;

b. Keputusan pemerintah lokal sangat responsif terhadap kebutuhan masyarakat, sehingga mendorong pemerintah lokal untuk melakukan efisiensi dalam penggunaan dana yang berasal dari masyarakat;

c. Persaingan antar daerah dalam memberikan pelayanan kepada masyarakatnya akan mendorong pemerintah lokal untuk meningkatkan inovasinya.

Berdasarkan temuan tersebut, perlu dibangun kebijakan baru tentang model hubungan keuangan antara pemerintah pusat dengan pemerintah daerah misalnya dengan pengembangan teori asimetri desentralisasi fiskal. Diperlukan model alternatif tentang bagaimana desentralisasi fiskal diterapkan dengan secara berbeda berbasis kondisi daerah otonom (baru terbentuk atau sudah lama berdiri) sehingga tujuan kemandirian daerah dapat diwujudkan melalui kebijakan desentralisasi fiskal ini.

\section{UCAPAN TERIMA KASIH}

Ucapan terima kasih disampaikan kepada seluruh pihak yang telah memberikan kesempatan dalam penulisan artikel ini.

\section{DAFTAR PUSTAKA}

Asmariadi, Adi dan Fauzzela, Dian Sera. 2021. Dana Kegesitan (Agility Funding): Sebuah Manifesto Bagi Pemerintah dalam Menghadapi Lingkungan Disruptif. Jurnal Inovasi Pembangunan. Volume 09 Nomor 02, Agustus 2021.

Anwar, Ervina dkk. 2015. Analisis Kemandirian Fiskal Tahun 2010-2012 Daerah Kabupaten/Kota Sulawesi Utara. Universitas Sam Ratulangi:Jurnal Berkala Ilmiah Efisiensi.

Direktorat Jenderal Perimbangan Keuangan. Anggaran Pendapatan dan Belanja Daerah Kabupaten Tulang
Bawang Barat dan Pesisir Barat Tahun Anggaran 2018 s.d 2020.

Kartikasari, Rofiqoh dan Fuad. 2014. Pengaruh Tingkat Kemandirian dalam Memenuhi Kebutuhan Fiskal Daerah, Tingkat Kemandirian dalam Mengelola Potensi Daerah dan SiLPA Terhadap Tingkat Kinerja Pelayanan Publik. Universitas Diponegoro:Journal of Accounting.

Lubis dkk. 2017. Pengaruh Pertumbuhan Ekonomi Terhadap Derajat Desentralisasi Fiskal di Kabupaten Tanjung Jabung Timur: Jurnal Perspektif Ekonomi dan Pembangunan Daerah Vol. 6. No. 3.

Mukhlis, Maulana dan Makhya, Syarief. 2019. Implikasi Desentralisasi Fiskal Terhadap Kemandirian Daerah Pasca Pemekaran: CosmoGov Jurnal Ilmu Pemerintahan. Vol. 5 No. 2.

Mardiasmo. 2004. Otonomi dan Manajemen Keuangan Daerah. Penerbit Andi, Yogyakarta.

Rahmawati, Rita. 2011. Derajat Desentralisasi Fiskal dan Kemandirian Daerah Kotamadya Metro dan Lampung Timur. Universitas Ahmad Dahlan:Jurnal of Economics and Business.

Rusdiana, Andarwati. 2017. Analisis Kemandirian Fiskal dalam Era Otonomi dan Pengaruhnya Terhadap Pertumbuhan Ekonomi Daerah Jawa Timur. Universitas Brawijaya: Jurnal Ilmiah Mahasiswa Fakultas Ekonomi dan Bisnis.

Saifuddin, Ridwan. 2020. Pemanfaatan Teknologi Informasi dalam Peningkatan Pendapatan Asli Daerah. Jurnal Inovasi Pembangunan. Volume 08 Nomor 02, Agustus 2020.

Sugiyono. 2012. Metode Penelitian Kuantitatif, Kualitatif, $\mathrm{R} \& \mathrm{D}$. Bandung:Alfabeta.

Undang-Undang Nomor 22 Tahun 2012 tentang Pembentukan Kabupaten Pesisir Barat.

Undang-Undang Nomor 23 Tahun 2014 tentang Pemerintah Daerah. 
Undang-Undang Nomor 33 Tahun 2004 tentang Perimbangan Keuangan Antara Pemerintah Pusat dan Daerah.

Undang-Undang Nomor 50 Tahun 2008 tentang Pembentukan Kabupaten Tulang Bawang Barat.

Wardhanu, Luqman dan Santosa, Dwi Budi. 2013. Analisis Implementasi Desentralisasi Serta Dampaknya Terhadap Kemandirian Fiskal dan Dana Alokasi Belanja Publik. Universitas Brawijaya: Jurnal Ilmiah Mahasiswa Fakultas Ekonomi dan Bisnis.

Yani, Ahmad. 2004. Hubungan Keuangan Antara Pemerintah Pusat dan. Daerah. Jakarta : PT Raja Grafindo Persada. 
